\title{
ABO Incompatibility as a Cause of Spontaneous Abortion: Evidence from Abortuses*
}

\author{
K. TAKANO and J. R. MILLER
}

\author{
The Division of Medical Genetics, Department of Paediatrics, University of British Columbia, Vancouver, Canada
}

Although ABO incompatibility between mother and the conceptus has long been suspected as a cause of spontaneous abortion in man its precise contribution has not been completely resolved (Levene and Rosenfield, 1961). In spite of reports in which the incompatible mating was recognized to be a cause of habitual abortion (McNeil et al, 1954) and which eventually results in infertility (Behrman et al, 1960) or a reduction in the mean number of living children compared to the number in compatible matings (Matsunaga and Itoh, 1957/ 1958), such effects were not observed in other studies (Peritz, 1966/1967; Reed, 1968; Solish and Gerschowitz, 1969). Recently, Cohen (1970a) and Peritz (1971) reported a significantly higher fetal mortality in incompatible matings by a statistical analysis of complete reproductive data (ie, including stillbirths) and it has been assumed that the previous negative results might be due, at least in part, to limitation of the analysis to live births (Cohen, 1970a).

In all of these reports data were analysed by comparing the fertility between compatible and incompatible matings, which were classified according to maternal and paternal blood types. To the best of our knowledge there has been only one report in which blood types of abortuses as well as the parents were examined, and the data were analysed on the basis of maternal-fetal incompatibility (Krieg and Kasper, 1968). These authors used the haemagglutination-inhibition technique to identify blood types of fresh fetal organs in a relatively small number of specimens, and no statistical analysis was described. According to the study of Coombs and his colleagues the mixed agglutination technique is the most sensitive and it is possible to identify the blood types of old, dried, or even fixed blood, and some other tissues by its application (Holborow et al, 1960; Coombs and Dodd, 1961). Since a large

\footnotetext{
Received 15 November 1971.

* Reprint requests to: J. R. Miller, Department of Paediatrics, 715 West 12th Avenue, Vancouver, British Columbia, Canada.
}

number of abortuses were available to us through an ongoing research project at the Vancouver General Hospital (Poland, 1968) we applied this technique to identify the blood type of spontaneously aborted fetuses with the purpose of estimating the maternalfetal ABO incompatibility as a cause of spontaneous abortion.

\section{Materials and Methods}

Details of the procedures of collecting the abortuses have been reported elsewhere (Poland, 1968). The developmental stages of the abortuses used in our study ranged from $17 \mathrm{~mm}$ in crown-rump length (35-40 days of ovulation age) to $180 \mathrm{~mm}$ (approximately 135 days). In the case of fresh specimens drops of blood direct from the umbilical cord were placed on a clean lens paper. When the fetuses had been fixed by formalin $(10 \%)$ blood coagula were taken from the heart or the cranial sinuses and rubbed repeatedly on to both sides of the lens paper. The lens paper was allowed to dry for 1 hour and then treated with pure methanol for 5 minutes to fix the adhering corpuscular material more firmly to the paper. Under our own experimental conditions we confirmed the previous observations by Coombs and Dodd (1961) and Akaishi (1965) that fixation by formalin and/or methanol has little deleterious action on the blood group antigens to be tested, ie, immunopolysaccharides. Blood coated fibrils of the lens paper were teased apart and immersed in $2 \%$ acetic acid solution for a few seconds to make sure that all adhering corpuscular material was haemolysed so that there was no confusion between the test material and the indicator cells becoming attached in the later stages of the test. The treated fibrils were washed 3 times in a phosphate-buffered saline (in 1 litre: $\mathrm{NaCl}, 8.5 \mathrm{~g} ; \mathrm{Na}_{2} \mathrm{HPO}_{4}, 0.712 \mathrm{~g}$; $\mathrm{KH}_{2} \mathrm{PO}_{4}, 0.363 \mathrm{~g} ; p \mathrm{H} 7$ ). The same buffered saline was used throughout.

The specimens were divided into 3 test tubes with antisera* of one of the following: anti-A, anti-B, or control serum obtained from an $A B$ type donor. They were incubated overnight on an electric shaker at room temperature. The titre of the anti-A serum was 256

* 'Immune' antisera were provided for us through the courtesy of Dr T. D. Stout, Medical Director, Canadian Red Cross Blood Transfusion Service, Vancouver. 


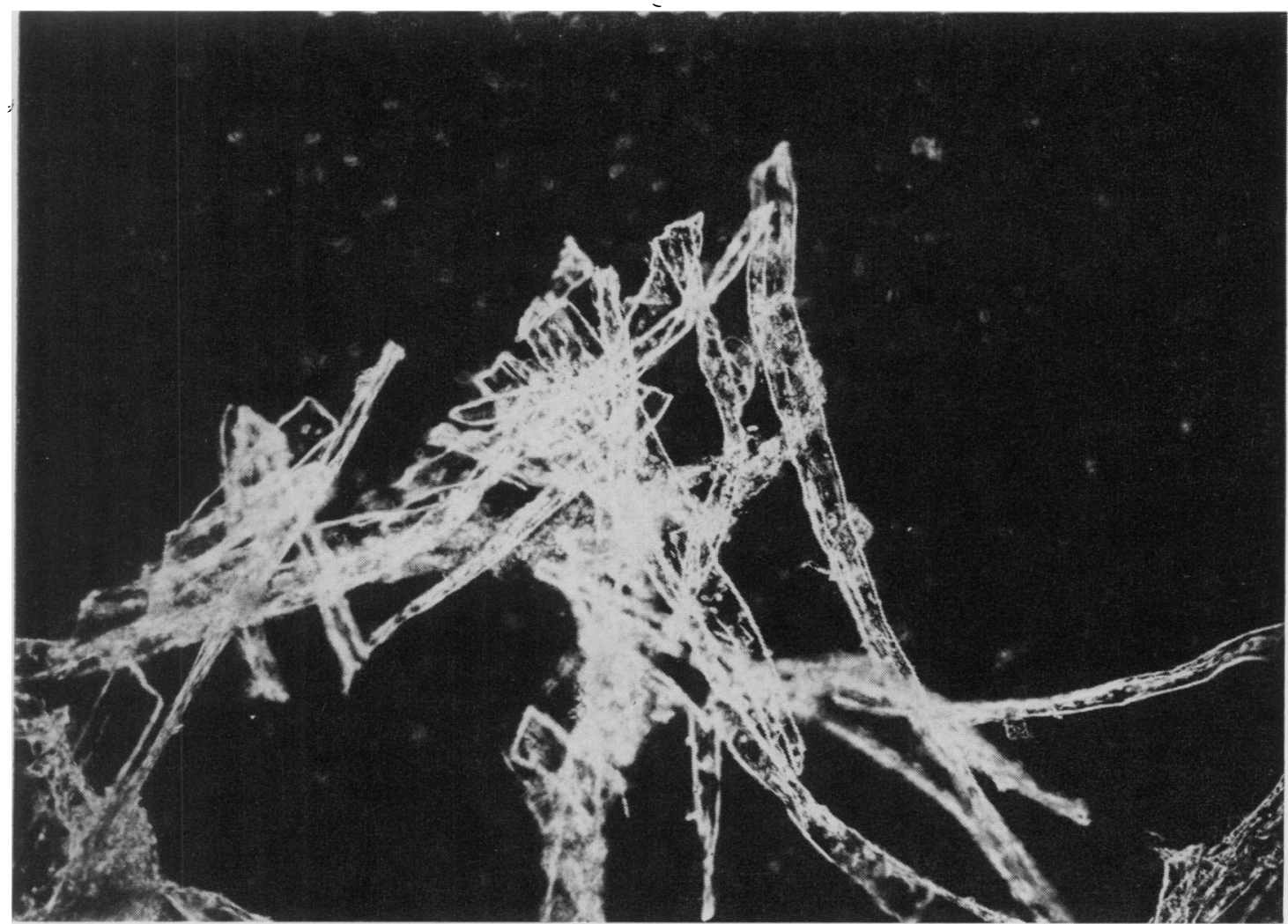

FIG. 1. Control specimen of blood stained fibrils incubated with serum of type AB blood and mixed with type $O$ indicator cells.

with $A_{2}$ cells and that of the anti-B was over 4000 . Each serum was inactivated at $56^{\circ} \mathrm{C}$ and diluted by the same amount of the buffered saline before use.

The treated fibrils were washed 3 times by the buffered saline to remove uncombined antibody. Finally $2-5 \%$ suspension of indicator cells (either A or B for the test specimens and $O$ cells for the control) in the buffered saline were added to each deposit of specimen and incubated for 1 hour. The specimens were then transferred by means of a pipette to a slide for microscopic examination (Figs. 1 and 2).

Various tissues, other than the blood cells, of the formalin-fixed fetus were also tested. The procedure was essentially the same as those mentioned above except that each tissue was teased into fine pieces and incubated with antisera without the pretreatment with acetic acid solution. In the case of the epithelial and entodermal tissues it was very difficult to prepare materials fine enough to see the agglutination figure under the microscope. As a result only tendinous fibres obtained from the abdominal wall (mostly from the external oblique muscle) were found to show distinct reactions consistent with those of the blood cells obtained from the same abortus (Figs. 3 and 4). Core tissues of cotyledons on the fetal side of the placenta were reported to have the blood antigens (Krieg and Kasper, 1968) and a similar result was obtained in our preliminary experiment (Takano and Miller, 1971). However, in a subsequent examination the reaction shown by the placental tissue was not consistent with that by the blood cells from the same fetus and it was concluded that the former was a non-specific agglutination.

\section{Results}

There were 234 patients during the last 6 years who had spontaneous abortions and whose $\mathrm{ABO}$ as well as $\mathrm{Rh}$ blood types were known. Amongst these, 5 patients who had aborted twins were not included in this study. Table I shows the distribution of blood types of the 229 patients who had aborted singletons.

The frequency of $O$ type mothers who are most likely to have spontaneous abortion, if in fact ABO incompatibility plays a role in this phenomen, is $52.0 \%$ and is appreciably higher than that in the general population of British Columbia (44.5\%); 


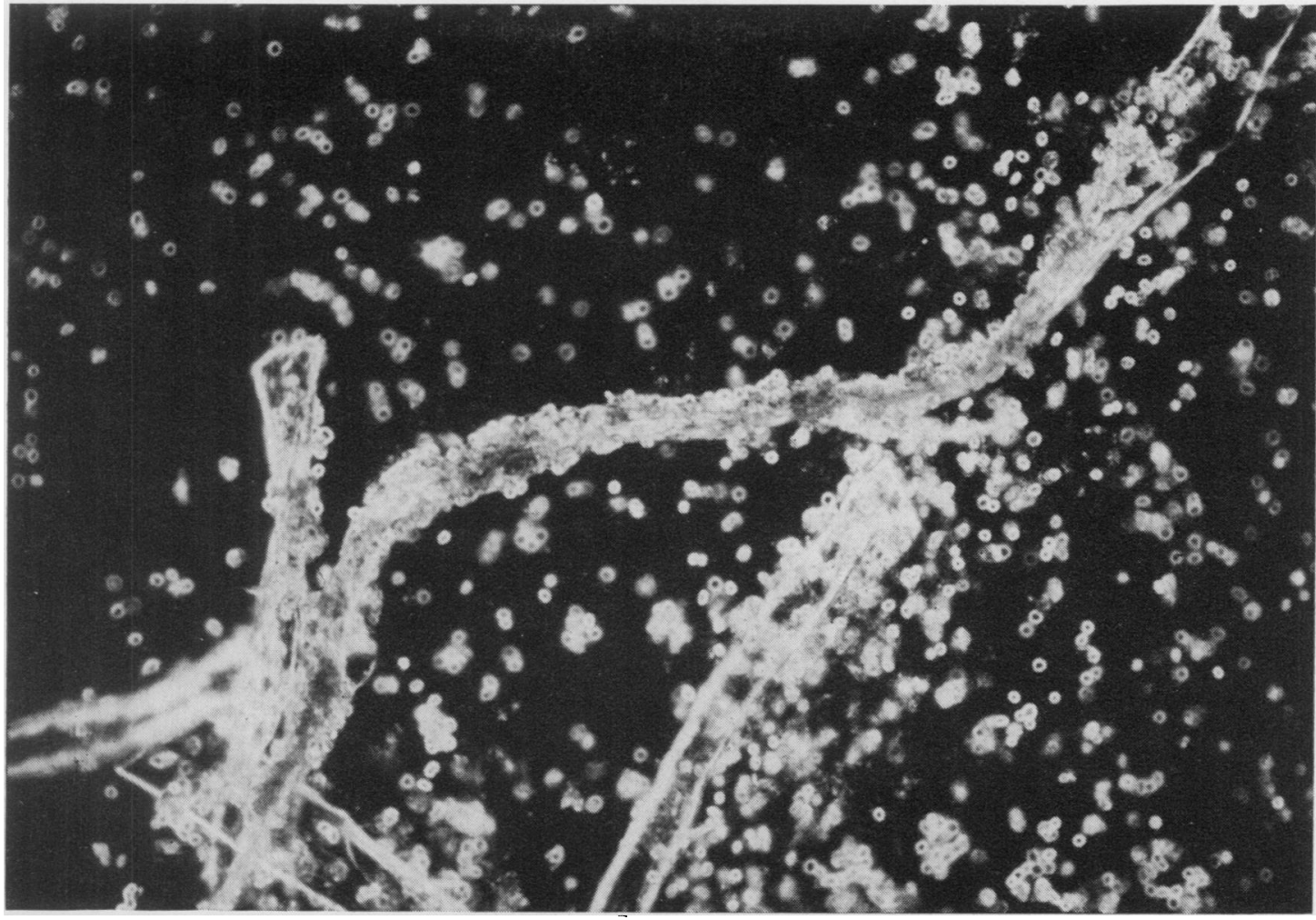

FIG. 2. The same specimen shown in Fig. 1 but incubated with anti-A serum and then mixed with type $\mathbf{A}$ indicator cells. There are clear figures of agglutination at most parts of the fibrils, indicating the test blood is type A. It is difficult to cover each fibril completely with test corpuscular material and there is always a negative figure at some parts of the specimen.

TABLE I

DISTRIBUTION OF ABO BLOOD TYPES OF MOTHERS OF SPONTANEOUS ABORTUSES AND OF THE GENERAL POPULATION OF BRITISH COLUMBIA

\begin{tabular}{|c|c|c|c|c|}
\hline \multirow{2}{*}{ Blood Type } & \multicolumn{3}{|c|}{ Mothers of Spontaneous Abortuses } & \multirow{2}{*}{$\begin{array}{l}\text { General Population } \\
\text { in British Columbia }\end{array}$} \\
\hline & Rh Positive & Rh Negative & Total & \\
\hline $\begin{array}{l}\mathrm{O} \\
\mathrm{A} \\
\mathrm{B} \\
\mathrm{AB}\end{array}$ & $\begin{array}{r}88 \\
69 \\
17 \\
3 \\
\end{array}$ & $\begin{array}{r}31 \\
16 \\
4 \\
1 \\
\end{array}$ & $\begin{array}{c}119\left(52 \cdot 0^{\circ}{ }^{\circ}\right)^{*} \\
85\left(37 \cdot 1^{\circ}{ }_{0}\right) \\
21\left(9 \cdot 0^{\circ}{ }_{0}\right) \\
4\left(1 \cdot 7_{0}^{\circ}\right)\end{array}$ & $\begin{array}{c}44.5 \% \% \\
40.5 \% \% \\
10.5 \% \\
4.5 \%\end{array}$ \\
\hline Total & $177\left(77 \cdot 3^{\circ}{ }_{0}\right)$ & $52\left(22 \cdot 7^{\circ}{ }_{0}\right) \dagger$ & $229\left(100^{\circ}\right)$ & $100^{\circ}$ \\
\hline
\end{tabular}

* Difference is not significant $(0 \cdot 1<\mathrm{p}<0 \cdot 2)$.

† This figure is not significantly different from the general distribution of Rh-negative individuals in British Columbia $\left(16 \cdot 8^{\circ}\right)(0 \cdot 1<\mathrm{p}<0 \cdot 2)$.

but the difference is not statistically significant $(0 \cdot 1<\mathrm{p}<0 \cdot 2)$. Neither was there any significant difference in the frequency of $\mathrm{Rh}$-negative individuals amongst the mothers of abortuses and in the general population.

Some of the specimens consisted of empty chorionic sacs containing no visible embryonic tissue proper, or if the embryo was present it had severe growth disorganization (Poland, 1968), with extensive maceration and no significant amount of fetal blood. Excluding these and some other cases which had been used for other purposes 78 abortuses were available for $\mathrm{ABO}$ typing.

Table II shows the results of the blood typing of the abortuses. There was no significant difference in the frequency of $\mathrm{ABO}$ incompatible abortuses 


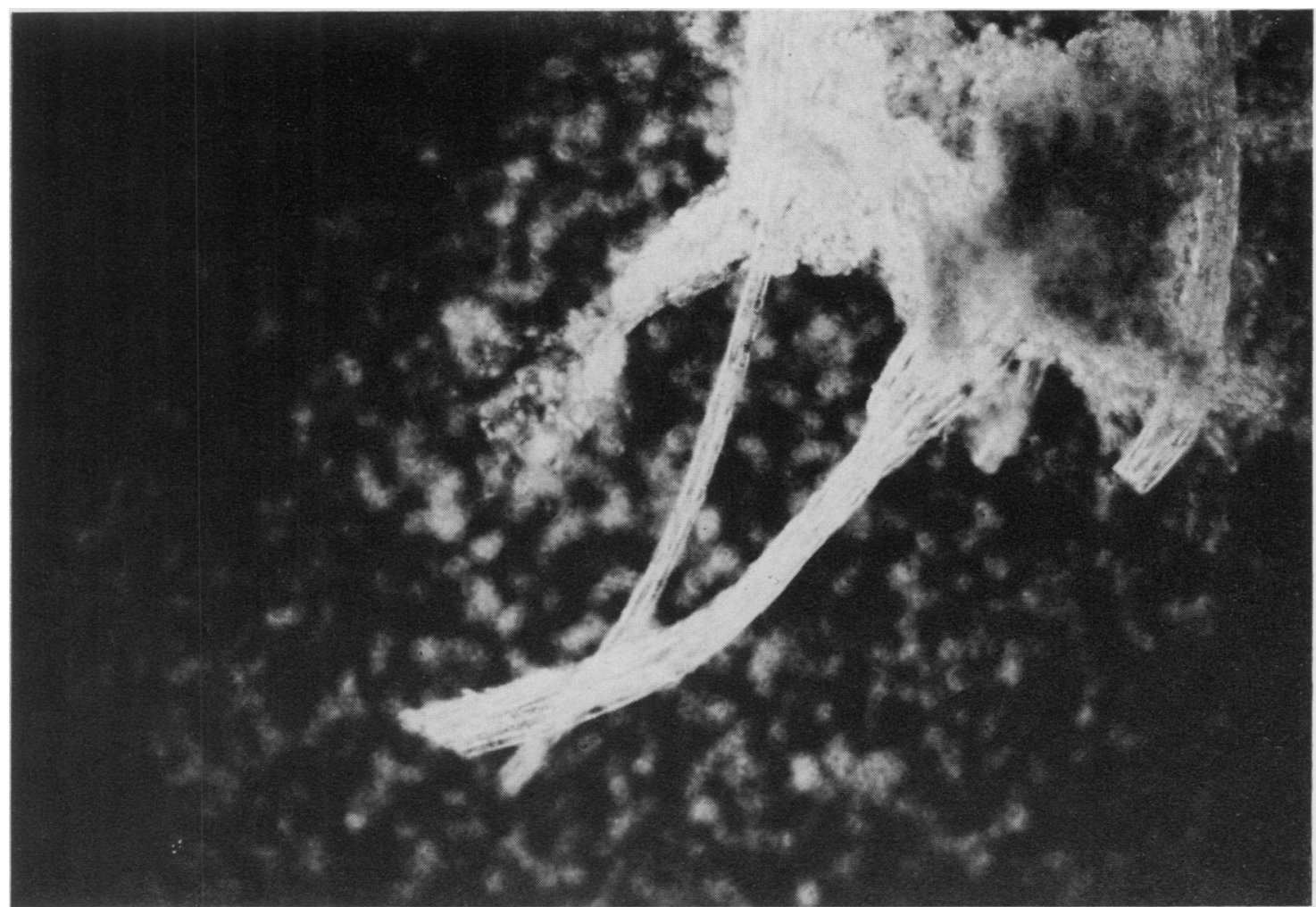

Fig. 3. Control specimen of the tendinous fibres incubated with serum of type $A B$ blood and mixed with type $O$ indicator cells. This specimen was obtained from the same individual as the specimens shown in Figs. 1 and 2.

TABLE II

MATERNAL-FETAL ABO INCOMPATIBILITY IN RELATION TO MATERNAL RH FACTOR AND ABO BLOOD TYPES

\begin{tabular}{|c|c|c|c|c|c|c|c|}
\hline \multirow{3}{*}{$\begin{array}{l}\text { Type of } \\
\text { Mother }\end{array}$} & \multicolumn{2}{|c|}{ Rh Fositive } & \multicolumn{2}{|c|}{ Rh Negative } & \multicolumn{3}{|c|}{ Total } \\
\hline & \multirow{2}{*}{$\begin{array}{l}\text { Examined } \\
\text { Abortuses }\end{array}$} & \multirow{2}{*}{$\begin{array}{c}\text { Incompatible } \\
\text { Abortuses }\end{array}$} & \multirow{2}{*}{$\begin{array}{l}\text { Examined } \\
\text { Abortuses }\end{array}$} & \multirow{2}{*}{$\begin{array}{c}\text { Incompatible } \\
\text { Abortuses }\end{array}$} & \multirow{2}{*}{$\begin{array}{l}\text { Examined } \\
\text { Abortuses }\end{array}$} & \multicolumn{2}{|c|}{ Incompatible Abortuses } \\
\hline & & & & & & Observed & Expected* \\
\hline $\begin{array}{l}\mathrm{O} \\
\mathrm{A} \\
\mathrm{B} \\
\mathrm{AB}\end{array}$ & $\begin{array}{r}31 \\
24 \\
6 \\
1\end{array}$ & $\begin{array}{r}17 \\
6 \\
5 \\
0\end{array}$ & $\begin{array}{l}5 \\
8 \\
2 \\
1\end{array}$ & $\begin{array}{l}3 \\
4 \\
0 \\
0\end{array}$ & $\begin{array}{r}36 \\
32 \\
8 \\
2\end{array}$ & $\begin{array}{r}20 \\
10 \\
5 \\
0\end{array}$ & $\begin{array}{c}12 \\
2-3 \\
2 \\
0\end{array}$ \\
\hline Total & 62 & $28\left(45 \cdot 2^{\circ}, 0\right)$ & 16 & $7\left(43 \cdot 8^{\circ}{ }_{0}\right)$ & 78 & $35\left(44 \cdot 7^{\circ}\right) t$ & $\leqq 17$ \\
\hline
\end{tabular}

* These figures were calculated from expected incidences of incompatibility in each maternal ABO blood type shown in Table III.

† Significantly larger than the maximum expected figure $(17)(p<0.01)$.

between $\mathrm{Rh}$-positive and $\mathrm{Rh}$-negative mothers $(45 \cdot 2 \%$ versus $43 \cdot 8 \%)$, and therefore all cases were pooled. Expected frequencies of incompatible conceptuses were calculated, assuming that the blood type distribution amongst the fathers was the same as that in the general population and that there was no prezygotic selection (Table III).

The total number of incompatible abortuses ob- served was significantly greater than expected $(p<0.01)$. In other words, the incompatible conceptuses are more likely to be aborted than the compatible ones.

It seemed noteworthy that the frequency of developmental anomalies was apparently higher amongst the compatible abortuses. Among 43 such abortuses there were 8 anomalous fetuses (18.6\%), 
FIg. 4. The same specimen shown in Fig. 3 but incubated with anti-A serum and then mixed with type A indicator cells. The positive agglutination figure indicates these tendinous fibres contain $\mathrm{A}$ antigens.

TABLE III

EXPECTED INCIDENCE OF MATERNAL-FETAL ABO INCOMPATIBILITY IN RELATION TO MATERNAL ABO BLOOD TYPES*

\begin{tabular}{|c|c|c|c|c|}
\hline \multirow{2}{*}{ Phenotype of Mother } & \multirow{2}{*}{ Genotype of Father } & \multicolumn{2}{|c|}{ Frequency of Conceptuses } & \multirow{2}{*}{$\begin{array}{c}\text { Incidence of } \\
\text { Incompatibility }(\%)\end{array}$} \\
\hline & & Compatible & Incompatible & \\
\hline \multirow[t]{2}{*}{$\mathbf{O}$} & $\begin{array}{l}\text { OO } \\
\text { AA } \\
\text { AO } \\
\text { RB } \\
\text { BO } \\
\text { AB }\end{array}$ & $\begin{array}{c}0.198025 \\
- \\
0.075672 \\
0.022261 \\
-\end{array}$ & $\begin{array}{c}-\overline{0} \\
0.028925 \\
0.075672 \\
0.002503 \\
0.022261 \\
0.020025 \\
\end{array}$ & \multirow[t]{2}{*}{$33 \cdot 6$} \\
\hline & Total & 0.295958 & $0 \cdot 149386$ & \\
\hline \multirow[t]{2}{*}{ A } & $\begin{array}{l}\mathrm{OO} \\
\mathrm{AA}+\mathrm{AO} \\
\mathrm{BB} \\
\mathrm{BO} \\
\mathrm{AB} \\
\end{array}$ & $\begin{array}{c}0.180225 \\
0.164025 \\
0.020260 \\
0.009112 \\
\end{array}$ & $\begin{array}{c}\bar{z} \\
0.002278 \\
0.020260 \\
0.009112\end{array}$ & \multirow[t]{2}{*}{$7 \cdot 8$} \\
\hline & Total & $0 \cdot 373622$ & 0.031650 & \\
\hline \multirow[t]{2}{*}{ B } & $\begin{array}{l}\text { OO } \\
\text { AA } \\
\text { AO } \\
\text { BB + BO } \\
\text { AB } \\
\end{array}$ & $\begin{array}{l}0.046725 \\
0.017855 \\
0.011025 \\
0.002362 \\
\end{array}$ & $\begin{array}{c}0.00 \overline{6825} \\
0.017855 \\
0.002362\end{array}$ & $25 \cdot 8$ \\
\hline & Total & $0 \cdot 077967$ & 0.027042 & \\
\hline $\mathrm{AB}$ & All & 0.045 & - & 0 \\
\hline \multicolumn{2}{|c|}{ Total and average } & $0 \cdot 792547$ & $0 \cdot 208078$ & $20 \cdot 8$ \\
\hline
\end{tabular}

* These figures were calculated from the distribution of ABO blood types in the general population shown in Table I $(\mathrm{pA}=0.255, \mathrm{qB}=0.075, \mathrm{rO}=0.667)$. 
including 2 cases with chromosomal aberrations (45,X and D-chromosome satellite translocation), 2 with apparent Turner's syndrome in which the chromosome examination failed (Singh and Carr, 1966), one with micrognathus and other facial malformations, and 3 cases with various malformations of the internal organs. On the other hand, amongst 35 incompatible abortuses there were only 3 malformed fetuses $(8.6 \%)$, including 2 cases with umbilical hernia and one case with cleft lip and palate and a ventral septal defect.

\section{Discussion}

Szulman (1965) found that the ABH antigens were clearly demonstrated by the immunofluorescent technique in small embryos of $5-8 \mathrm{~mm}$ in crown-rump length. Therefore, there is good reason to believe that the blood antigens were well developed in the smallest embryo of $17 \mathrm{~mm}$ examined in the present study. Krieg and Kasper (1968) determined the ABO blood types of abortuses not exceeding 28 weeks of gestation by the agglutination inhibition technique. Gestational age of the youngest fetus was not described in their report, but their specimens were in general more advanced than ours. The frequency of maternal-fetal ABO incompatibility in their report was $44.3 \%$, which is quite similar to the $44.7 \%$ in the present study. They pointed out that the proportion of group $O$ abortuses was much lower than that amongst the German population but did not mention any statistical significance of their results.

In the present study a significantly higher incidence of maternal-fetal ABO incompatibility was observed in abortuses in comparison to the expected figure calculated from ABO blood type distribution in the general population. This evidence strongly suggests that the maternal-fetal incompatibility does play a role, at least in part, in the phenomenon of spontaneous abortion during the gestational period examined, ie, from 35 days to 135 days of ovulation age.

Cohen (1970b) has reported that an interaction between $\mathrm{ABO}$ incompatibility and $\mathrm{Rh}$ selection exists in regard to the spontaneous abortion, and that doubly incompatible matings have lower fetal loss rates than do singly incompatible matings, either $\mathrm{ABO}$ or $\mathrm{Rh}$. However, no such interaction between $A B O$ and $R h$ incompatibilities was obvious in the present study (see Table II). It seems to us that Cohen (1970b) has dealt with spontaneous abortions which occurred mainly in the perinatal period and that the discrepancy between her data and ours may be due to the difference of gestational stages of the specimens studied.
Other than the blood type incompatibility there will certainly be a great many other factors which cause spontaneous abortions. In this respect a higher incidence of morphological and chromosomal anomalies, which could be lethal to the conceptuses, was observed in the compatible abortuses $(18.6 \%$ versus $8.6 \%$ ). We could not identify the blood type of the fetal placental tissues and, therefore, did not examine the cases of empty sac and growth disorganization which are well known to show very high incidence of chromosomal aberrations (Carr, 1971; Poland and Miller, 1971). In any event, on the basis of this study it seems reasonable to conclude that maternal-fetal ABO incompatibility plays a role as an aetiological factor in some cases of spontaneous abortion.

\section{Summary}

Amongst 229 cases of spontaneous abortion not exceeding 20 weeks of gestation observed at the Vancouver General Hospital, the maternal blood type was distributed as follows: $\mathrm{O}, 52.0 \% ; \mathrm{A}, 37 \cdot 1 \%$; $\mathrm{B}, 9.2 \%$; $\mathrm{AB}, 1.7 \%$. The incidence of $\mathrm{O}$ type mothers who are most likely to have a spontaneous abortion if maternal-fetal ABO incompatibility does play a role in this phenomenon was considerably higher than in the general population of British Columbia (44.5\%). In order to observe exact maternal-fetal blood group relations in each case of spontaneous abortion, ABO blood types of the abortuses were tested by the mixed agglutination technique. For the test, fetal blood cells and tendinous fibres in the abdominal wall were used. Of the 78 fetuses examined, $35(44 \cdot 7 \%)$ were found to be incompatible with the mother. This frequency of incompatible cases was significantly higher than that expected $(p<0.01)$. There was no apparent interaction between the $A B O$ and $R h$ incompatibilities. It is concluded that maternalfetal ABO incompatibility is at least one of the major causes of spontaneous abortion in the gestational stages examined.

We wish to acknowledge with thanks the help of Dr B. J. Poland and Mrs Barbara Paradise in providing the specimens, of Dr T. D. Stout for the supply of immune antisera and for the information on blood type distribution in British Columbia, and of Miss Sharon Masui in carrying out the techniques of the mixed agglutination test. We are also indebted to Drs $M$. Yasuda and $H$. Nishimura (Kyoto University, Japan) for providing us with Japanese references as well as their personal experience in this study. This research was supported by a grant from the Medical Research Council of Canada No. MA-2740. 


\section{REFERENCES}

Akaishi, A. (1965). Studies on group specific double combination method. (In Japanese.) fapanese fournal of Legal Medicine, 19, 177-187.

Behrman, S. J., Buettner-Janusch, J., Heglar, R., Gershowitz, H., and Tew, W. L. (1960). ABO(H) blood incompatibility as a cause of infertility: A new concept. American fournal of Obstetrics and Gynecology, 79, 847-855.

Carr, D. H. (1971). Chromosome studies in selected spontaneous abortions: Polyploidy in man. Fournal of Medical Genetics, 8, 164174.

Cohen, B. H. (1970a). ABO and Rh incompatibility. I. Fetal and neonatal mortality with $\mathrm{ABO}$ and $\mathrm{Rh}$ incompatibility: Some new interpretations. American fournal of Human Genetics, 22, 412439.

Cohen, B. H. (1970b). ABO and Rh incompatibility. II. Is there a dual interaction in combined $\mathrm{ABO}$ and $\mathrm{Rh}$ incompatibility? American fournal of Human Genetics, 22, 441-452.

Coombs, R. R. A. and Dodd, B. (1961). Possible application of the principle of mixed agglutination in the identification of blood stains. Medicine, Science and the Law, 1, 359-377.

Holborow, E. J., Brown, P. C., Glynn, L. E., Hawes, M. D., Gresham, G. A., O'Brien, T. F., and Coombs, R. R. A. (1960), The distribution of the blood group $A$ antigen in human tissues. British fournal of Experimental Pathology, 41, 430-437.

Krieg, H. and Kasper, K. (1968). ABO incompatibility as a cause of abortion. German Medical Monthly, 13, 171-175.

Levene, $H$. and Rosenfield, R. E. (1961). ABO incompatibility. In Progress in Medical Genetics, vol. 1, pp. 120-157, ed. by A. G. Steinberg. Grune and Stratton, New York.

McNeil, C., Warenski, L. C., Fullmer, C. D., and Trentelman, E. F. (1954). A study of the blood groups in habitual abortion. American fournal of Clinical Pathology, 24, 767-773.
Matsunaga, E. and Itoh, S. (1957/1958). Blood groups and fertility in a Japanese population, with special reference to intrauterine selection due to maternal-foetal incompatibility. Annals of Human Genetics, 22, 111-131.

Peritz, E. (1966/1967). A statistical study of intrauterine selection factors related to the ABO system. I. The analysis of data on liveborn children. Annals of Human Genetics, 30, 259-271.

Peritz, E. (1971). A statistical study of the intrauterine selection factors related to the $\mathrm{ABO}$ system. II. The analysis of foetal mortality data. Annals of Human Genetics, 34, 389-394.

Poland, B. J. (1968). Study of developmental anomalies in the spontaneously aborted fetus. American fournal of Obstetrics and Gynecology, 100, 501-505.

Poland, B. J. and Miller, J. R. (1971). Observations on severe growth disorganization in human embryos. (Abstr.). Teratology, 4, 238.

Reed, T. E. (1968). Research on blood groups and selection from the Child Health and Development Studies, Oakland, California. III. Couple mating type and reproductive performance. American fournal of Human Genetics, 20, 129-141.

Singh, R. P. and Carr, D. H. (1966). The anatomy and histology of XO human embryos and fetuses. Anatomical Record, 155, 369384.

Solish, G. I. and Gerschowitz, H. (1969). Distribution of ABO blood types among fertile and infertile women. American fournal of Human Genetics, 21, 23-35.

Szulman, A. E. (1965). The ABH antigens in human tissues and secretions during embryonal development. Fournal of Histochemistry and Cytochemistry, 13, 752-754.

Takano, K. and Miller, J. R. (1971). ABO incompatibility as a possible cause of spontaneous abortion. (Abstr.) Teratology, 4, 243. 